\title{
Carbetocin versus Oxytocin in the Prevention of Postpartum Hemorrhage Following Vaginal Delivery in High Risk Patients
}

\author{
Mahmoud A. Abdelfath, Khaled M. Salama, Yehia M. Samir Edris, Amany M. Metwally
}

\begin{abstract}
Department of Obstetrics and Gynecology, Faculty of Medicine, Benha University, Egypt
\end{abstract}

Correspondence to: Amany M. Metwally, Department of Obstetrics and Gynecology, Faculty of Medicine, Benha University, Egypt

Email:

wishesonline4@gmail.com

Received:30 September 2019

Accepted: 9 February 2022

\section{Abstract}

Background: Postpartum hemorrhage is a life threatening situation and one of the important causes of maternal mortality and morbidity, worldwide. Aim of the work: To compare the efficacy of carbetocin and oxytocin in preventing postpartum hemorrhage following vaginal delivery in high risk groups. Patients and methods: 120 women with gestational age between 37-40 weeks at high risk for primary atonic postpartum hemorrhage and delivered vaginally were randomly divided into two groups. First group: included 60 women, they received carbetocin, 100 mcg IM. Second group: included 60 women, they received Oxytocin 5 IU IM. Both groups received their drug after fetal and before placental delivery.

a statistically significant difference between the two study groups regarding mean blood loss (276.93 \pm 120.87 versus $346.42 \pm 176.61)$, occurrence of PPH (3.3\% versus $13.3 \%$ ), hemoglobin and hematocrit difference between before and $24 \mathrm{~h}$ after delivery $(0.55 \pm 0.51$ versus $0.998 \pm 0.69, \mathrm{p}=0.002)(3.38 \pm 2.92$ versus $4.65 \pm 4.18, \mathrm{p}=0.002$ ) respectively and measured hemoglobin and hematocrit $24 \mathrm{~h}$ after delivery (being higher in carbetocin group). The effect of carbetocin as regard to estimated blood loss was more obvious in multiparous women. However, there was no significant difference between the two groups regarding need for other uterotonics, the need for blood transfusion and occurrence of nausea, vomiting, abdominal pain, flushing, tachycardia, hypotension, headache, itching and metallic taste. Conclusions: Carbetocin is a better alternative to oxytocin in prevention of PPH after vaginal delivery with similar side effects.

Keywords: Carbetocin, oxytocin, postpartum hemorrhage. 


\section{Introduction}

Postpartum hemorrhage (PPH) is a life threatening situation and one of the important causes of maternal mortality and morbidity, worldwide [1].Postpartum haemorrhage $(\mathrm{PPH})$ has been defined as a bleed of $500 \mathrm{ml}$ or more in vaginal deliveries and in excess of $1000 \mathrm{ml}$ in abdominal deliveries and is usually based on subjective observations [2]. Uterine atony is the most common cause of PPH which contributes to $80 \%$ of cases of PPH [3].

Risk factors for $\mathrm{PPH}$ include prolonged labor $\geq 12 \mathrm{~h}$, severe anemia, preeclampsia, antepartum hemorrhage, intrapartum blood loss, history of $\mathrm{PPH}$ or retained placenta, body mass index (BMI) $\geq 35$, polyhydramnios, multiple gestation , difficult instrumental delivery, grand multipara, chorioamnionitis and fibroids [4].

Active management of the third stage of labor, particularly Prophylactic administration of uterotonic agents could significantly reduce the rate of postpartum hemorrhage from $18 \%$ to $5 \%$ compared with that of expectant management [5].

Oxytocin is the most commonly used uterotonic agent because it is at least as effective as ergot alkaloids or prostaglandins and has fewer side effects [6 \& 7]. Although oxytocin is rapidly effective and well tolerated, it has short half-life 4-10 min that means it must be administered by continuous intravenous infusion to achieve sustained uterotonic activity.

Carbetocin is a long- acting synthetic analogue of oxytocin with a half-life of 40 minutes, 4 to 10 times longer than that of oxytocin [8]. The onset of action occurs within $2 \mathrm{~min}$, and the duration of action is 1 and $2 \mathrm{~h}$ after intravenous and intramuscular injection, respectively [9 \&10].

The purpose of this study was to compare the efficacy of carbetocin and oxytocin in preventing postpartum haemorrhage following vaginal delivery in high risk groups.

\section{Subjects and methods}

This comparative study was conducted at the emergency unit of the Department of Obstetrics and Gynecology, Benha Teaching Hospital, through the period started from November 2016 to December 2018. The study was applied on 120 candidates randomly into two groups; achieve the inclusion and exclusion criteria. The study protocol was approved by the Local Ethics 
Committee and written informed consent was taken from each patient before beginning the study.

Candidates at 37-40 weeks of gestational age with risk factors for developing primary atonic postpartum hemorrhage and delivered vaginally, this risk factors include: history of previous postpartum hemorrhage, multiple gestation, fetal macrosomia, polyhydramnios, chorioamnionitis, induction or augmentation of labor with oxytocin for $>12$ hours, prolonged labor, grand multipara, body mass index > 35. Putting into consideration the following exclusion criteria: placenta previa, preeclampsia, cardiac, renal or liver diseases, coagulopathy, women with cervical or vaginal tears, known hypersensitivity to oxytocin or carbetocin, refusal to participate in the study.

All patients were subjected to full history taking, general, abdominal and obstetric examination. Ultrasound scan, complete blood picture, liver functions and coagulation profile were also done.

The patients included in this study were divided randomly into two groups:

First group:- sixty women were injected intramuscularly by single dose of carbetocin $100 \mu \mathrm{g}$ immediately after fetal and before placental delivery.
Second group:- sixty women were injected intramuscularly by 5IU oxytocin immediately after fetal and before placental delivery.

All participants were followed-up for $24 \mathrm{~h}$. The uterine tone and amount of bleeding were noted and the need for further uterotonic agents was checked also need for blood transfusion. Blood loss was estimated by weighing the swabs and using pictorial charts. PPH was defined as bleeding $\geq 500$ $\mathrm{ml}$. Blood hemoglobin and hematocrit were assessed $24 \mathrm{~h}$ after delivery. We recorded possible complications like nausea, vomiting, abdominal pain, flushing, tachycardia, hypotension, headache, itching and metallic taste.

Data were statistically described in terms of mean \pm standard deviation $( \pm \mathrm{SD})$, or frequencies (number of cases) and percentages when appropriate. Comparison of numerical variables between the study groups was done using independent t-test. For comparing categorical data, Chi square (z2) test was performed. Exact test was used instead when the expected frequency is less than 5. $\mathrm{p}$ values less than 0.05 were considered statistically significant. All statistical calculations were done using computer program SPSS (Statistical Package for the Social Science; SPSS Inc., Chicago, 
IL) release 15 for Microsoft Windows (2006).

\section{Results}

The 120 patients were classified into two groups: First group included 60 patients who received carbetocin and Second group included 60 patients who received oxytocin.

Baseline characteristics of the groups are summarized in (Table 1). There was no significant difference between the groups in age, parity, body mass index, gestational age, fetal birth weight and episiotomy.

Risk factors for atonic PPH were not significantly different between the groups (Table 2).
The amount of bleeding and occurrence of PPH were significantly lower in the carbetocin group (Table 3). The difference between blood hemoglobin levels before delivery and $24 \mathrm{~h}$ after delivery were significantly lower in the carbetocin group (Table 4). On the other hand, there was no significant difference between the two groups regarding need for other uterotonics and the need for blood transfusion (Table $5)$.

Regarding drugs side effects, there was no significant difference between the two groups regarding occurrence of nausea, vomiting, abdominal pain, flushing, tachycardia, hypotension, headache, itching, metallic taste(Table 6).

Table (1): Demographic and characteristic data of participants

\begin{tabular}{|c|c|c|c|c|c|c|c|}
\hline Variable & Drug & & $\begin{array}{l}\text { Mean (SD) } \\
\text { Or n }(\%)\end{array}$ & Min. & Max. & Test & $P$ value \\
\hline $\begin{array}{l}\text { Age } \\
\text { (years) }\end{array}$ & $\begin{array}{l}\text { Carbetocin } \\
\text { Oxytocin }\end{array}$ & & $\begin{array}{l}30.68(8.41) \\
30.78(8.46)\end{array}$ & $\begin{array}{l}18 \\
18\end{array}$ & $\begin{array}{l}45 \\
46\end{array}$ & $t=0.065$ & $\begin{array}{l}0.965 \\
\text { NS }\end{array}$ \\
\hline Parity & $\begin{array}{l}\text { Carbetocin } \\
\text { Oxytocin }\end{array}$ & $\begin{array}{l}\text { Nulliparous } \\
\text { Multiparous } \\
\text { Nulliparous } \\
\text { Multiparous }\end{array}$ & $\begin{array}{l}29(48.3 \%) \\
31(51.7 \%) \\
27(45.0 \%) \\
33(55.0 \%)\end{array}$ & $\begin{array}{l}- \\
1 \\
- \\
1\end{array}$ & $\begin{array}{l}- \\
7 \\
- \\
7\end{array}$ & $\chi^{2}=0.134$ & $\begin{array}{l}0.714 \\
\text { NS }\end{array}$ \\
\hline $\begin{array}{l}\text { BMI } \\
\quad\left(\mathrm{kg} / \mathrm{m}^{2}\right) \\
\text { Gestational age } \\
\text { (weeks) }\end{array}$ & $\begin{array}{l}\text { Carbetocin } \\
\text { Oxytocin } \\
\text { Carbetocin } \\
\text { Oxytocin }\end{array}$ & & $\begin{array}{l}27.997(4.79) \\
28.280(4.87) \\
38.29(0.92) \\
38.31(0.93)\end{array}$ & $\begin{array}{l}20 \\
19 \\
37 w \\
37 w\end{array}$ & $\begin{array}{l}37 \\
38 \\
40 \mathrm{w} \\
40 \mathrm{w}\end{array}$ & $\begin{array}{l}\mathrm{t}=0.321 \\
\mathrm{t}=0.155\end{array}$ & $\begin{array}{l}0.933 \\
\text { NS } \\
0.877 \\
\text { NS }\end{array}$ \\
\hline $\begin{array}{l}\text { Birth weight } \\
\text { (grams) }\end{array}$ & $\begin{array}{l}\text { Carbetocin } \\
\text { Oxytocin }\end{array}$ & & $\begin{array}{l}2959.83(887.71) \\
2963.67(839.53)\end{array}$ & $\begin{array}{l}1700 \\
1800\end{array}$ & $\begin{array}{l}4800 \\
4800\end{array}$ & $\mathrm{t}=0.024$ & $\begin{array}{l}0.981 \\
\text { NS }\end{array}$ \\
\hline Episiotomy & $\begin{array}{l}\text { Carbetocin } \\
\text { Oxytocin }\end{array}$ & $\begin{array}{l}\text { Yes } \\
\text { No } \\
\text { Yes } \\
\text { No }\end{array}$ & $\begin{array}{l}28(46.7 \%) \\
32(53.3 \%) \\
29(48.3 \%) \\
31(51.7 \%)\end{array}$ & $\begin{array}{l}- \\
- \\
- \\
-\end{array}$ & $\begin{array}{l}- \\
- \\
-\end{array}$ & $\chi^{2}=0.033$ & $\begin{array}{l}0.855 \\
\text { NS }\end{array}$ \\
\hline
\end{tabular}

Based on table (1) findings; there were no significant statistical differences between the Carbetocin and Oxytocin groups for all demographic variables at 0.05 level of significant. 
Benha medical journal, vol.xx, issue xx, 2022

Table (2): Distribution of risk factors for postpartum hemorrhage among both groups

\begin{tabular}{|c|c|c|c|c|}
\hline $\begin{array}{l}\text { Variable } \\
\text { (Yes) }\end{array}$ & Drug & n (\%) & $\chi^{2}-$ Test & $P$ value \\
\hline history of previous postpartum hemorrhage & $\begin{array}{l}\text { Carbetocin } \\
\text { Oxytocin }\end{array}$ & $\begin{array}{c}6(10 \%) \\
8(13.3 \%)\end{array}$ & 0.323 & NS \\
\hline multiple gestation & $\begin{array}{l}\text { Carbetocin } \\
\text { Oxytocin }\end{array}$ & $\begin{array}{c}4(6.7 \%) \\
3(5 \%)\end{array}$ & 1.009 & NS \\
\hline fetal macrosomia & $\begin{array}{l}\text { Carbetocin } \\
\text { Oxytocin }\end{array}$ & $\begin{array}{l}5(8.3 \%) \\
4(6.7 \%)\end{array}$ & 0.120 & NS \\
\hline polyhydramnios & $\begin{array}{l}\text { Carbetocin } \\
\text { Oxytocin }\end{array}$ & $\begin{array}{l}6(10 \%) \\
4(6.7 \%)\end{array}$ & 1.483 & NS 0.477 \\
\hline chorioamnionitis & $\begin{array}{l}\text { Carbetocin } \\
\text { Oxytocin }\end{array}$ & $\begin{array}{c}8(13.3 \%) \\
10(16.7 \%)\end{array}$ & 0.261 & NS \\
\hline $\begin{array}{l}\text { induction or augmentation of labor with } \\
\text { oxytocin for }>4 \text { hours }\end{array}$ & $\begin{array}{l}\text { Carbetocin } \\
\text { Oxytocin }\end{array}$ & $\begin{array}{c}13(21.7 \%) \\
12(20 \%)\end{array}$ & 0.051 & NS \\
\hline prolonged labor & $\begin{array}{l}\text { Carbetocin } \\
\text { Oxytocin }\end{array}$ & $\begin{array}{l}13(21.7 \%) \\
14(23.3 \%)\end{array}$ & 0.048 & NS \\
\hline grand multipara & $\begin{array}{l}\text { Carbetocin } \\
\text { Oxytocin }\end{array}$ & $\begin{array}{c}4(6.7 \%) \\
3(5 \%)\end{array}$ & 0.152 & NS \\
\hline body mass index > 35 & $\begin{array}{l}\text { Carbetocin } \\
\text { Oxytocin }\end{array}$ & $\begin{array}{l}4(6.7 \%) \\
5(8.3 \%)\end{array}$ & 1.009 & NS \\
\hline 2 risk factors & $\begin{array}{l}\text { Carbetocin } \\
\text { Oxytocin }\end{array}$ & $\begin{array}{l}3(5 \%) \\
3(5 \%)\end{array}$ & 0.000 & NS 1 \\
\hline
\end{tabular}

Based on table (2) findings; there were no significant statistical differences between Carbetocin and Oxytocin groups as regards risk factors for postpartum hemorrhage (P > $0.05)$.

Table (3): Comparing the effects of the two drugs on blood loss.

\begin{tabular}{|c|c|c|c|c|c|c|}
\hline Variable & Drug & $\begin{array}{l}\text { Mean (SD) } \\
\text { Or n (\%) }\end{array}$ & Min. & Max. & Test & $P$ value \\
\hline \multirow{2}{*}{ Estimated blood loss } & Carbetocin & 276.93 (120.87) & 80 & 650 & \multirow{2}{*}{$t=-2.52$} & 0.013 \\
\hline & Oxytocin & $346.42(176.61)$ & 90 & 880 & & Sig. \\
\hline \multirow{2}{*}{$\begin{array}{l}\text { Postpartum } \\
\text { hemorrhage } \\
\geq 500\end{array}$} & Carbetocin & $2(3.3 \%)$ & - & - & \multirow{2}{*}{$\chi^{2}=3.927$} & \multirow{2}{*}{$\begin{array}{l}0.048 \\
\text { Sig. }\end{array}$} \\
\hline & Oxytocin & $8(13.3 \%)$ & - & - & & \\
\hline
\end{tabular}

Based on table (3) :there was a statistically significant difference for the estimated blood loss between two drugs $(p=0.013)$ for Carbetocin group.there was a statistically significant difference for the postpartum hemorrhage between the two drugs $(p=0.048)$ for Carbetocin group.

Table (4): HB and HCT differences pre and 24h post-delivery in carbetocin and oxytocin groups.

\begin{tabular}{llllll}
\hline Characteristics & Drug & Mean (SD) & Min. & Max. & P value \\
\hline \multirow{2}{*}{ HB difference } & Carbetocin & $0.55(0.51)$ & 0.1 & 2.80 & \\
HCT difference & Oxytocin & $0.998(0.69)$ & 0.2 & 2.80 & \\
& Carbetocin & $3.38(2.92)$ & 1.0 & 15 & 0.002 Sig. \\
& Oxytocin & $4.56(4.18)$ & 1.0 & 19 & 0.047 Sig. \\
\hline
\end{tabular}


Based on table (4) findings; there were a statistically significant difference between $\mathrm{HB}$ and HCT levels before and $24 \mathrm{~h}$ after delivery being lower in the carbetocin group. Table (5): Additional requirements for the patient in carbetocin and oxytocin groups.

\begin{tabular}{lllcl}
\hline Variable & Drug & Or n (\%) & $\chi^{2}-$ Test & P value \\
\hline $\begin{array}{l}\text { Requirement of additional } \\
\text { uterotonic medication }\end{array}$ & $\begin{array}{l}\text { Carbetocin } \\
\text { Oxytocin }\end{array}$ & $8(13.3 \%)$ & 0.261 & 0.609 \\
Needs for blood transfusion & $\begin{array}{l}\text { Carbetocin } \\
\text { Oxytocin }\end{array}$ & $1(16.7)$ & \multirow{2}{*}{0.342} & 0.559 \\
& $2(3.3 \%)$ & & NS \\
\hline
\end{tabular}

Based on table (5) findings; there were no significant statistical differences between the two drugs for additional requirements.

Table (6): Comparison between Carbetocin and Oxytocin groups as regard side effects.

\begin{tabular}{|c|c|c|c|c|}
\hline $\begin{array}{l}\text { Variable } \\
\text { (Yes) }\end{array}$ & Drug & n (\%) & Test & $P$ value \\
\hline \multirow{2}{*}{ Nausea } & Carbetocin & $1(1.7 \%)$ & \multirow{2}{*}{$\chi^{2}=2.00$} & 0.368 \\
\hline & Oxytocin & $1(1.7 \%)$ & & NS \\
\hline \multirow{2}{*}{ Vomiting } & Carbetocin & $2(3.3 \%)$ & \multirow{2}{*}{$\chi^{2}=0.342$} & 0.559 \\
\hline & Oxytocin & $1(1.7 \%)$ & & \\
\hline \multirow{2}{*}{ Abdominal pain } & Carbetocin & $1(1.7 \%)$ & \multirow{2}{*}{$\chi^{2}=0.342$} & 0.559 \\
\hline & Oxytocin & $2(3.3 \%)$ & & NS \\
\hline \multirow{2}{*}{ flushing } & Carbetocin & $1(1.7 \%)$ & \multirow{2}{*}{$\chi^{2}=0.342$} & 0.559 \\
\hline & Oxytocin & $2(3.3 \%)$ & & NS \\
\hline \multirow{2}{*}{ Tachycardia } & Carbetocin & $2(3.3 \%)$ & \multirow{2}{*}{$\chi^{2}=0.342$} & 0.559 \\
\hline & Oxytocin & $2(3.3 \%)$ & & NS \\
\hline \multirow{2}{*}{ Hypotension } & Carbetocin & $1(1.7 \%)$ & \multirow{2}{*}{$\chi^{2}=0.000$} & 1.000 \\
\hline & Oxytocin & $1(1.7 \%)$ & & NS \\
\hline \multirow{2}{*}{ Headache } & Carbetocin & $1(1.7 \%)$ & \multirow{2}{*}{$\chi^{2}=1.034$} & 0.309 \\
\hline & Oxytocin & $3(5 \%)$ & & NS \\
\hline \multirow{2}{*}{ Itching } & Carbetocin & $3(5 \%)$ & \multirow{2}{*}{$\chi^{2}=1.034$} & 0.309 \\
\hline & Oxytocin & $1(1.7 \%)$ & & NS \\
\hline \multirow{2}{*}{ Metallic taste } & Carbetocin & $0(0 \%)$ & \multirow{2}{*}{$\chi^{2}=1.008$} & 0.315 \\
\hline & Oxytocin & $1(1.7 \%)$ & & NS \\
\hline
\end{tabular}

Based on table (6) findings; there were no significant statistical differences between the two drugs for all side effects at 0.05 level of significant.

\section{Discussion}

Our results have shown that carbetocin is superior to oxytocin in prevention of $\mathrm{PPH}$ after vaginal delivery in women with risk factors for developing atonic PPH. This fact can be explained by the known longer halflife of carbetocin when compared to oxytocin causing a more uterine response, in terms of frequency and amplitude of uterine contractions [11].

$100 \mu \mathrm{g}$ IM carbetocin given to women at high risk for PPH had a higher efficacy than 5 IU IM oxytocin regarding mean blood loss 
$(276.93 \pm 120.87$ versus $346.42 \pm 176.61)$, occurrence of postpartum haemorrhage $(3.3 \%$ versus $13.3 \%)$,hemoglobin and hematocrit difference between before and $24 \mathrm{~h}$ after delivery $(0.55 \pm 0.51$ versus 0.998 $\pm 0.69, \mathrm{p}=0.002)(3.38 \pm 2.92$ versus $4.65 \pm$ 4.18, $\mathrm{p}=0.002$ ) respectively. This agrees with some studies (12, 16 and 17) while disagrees with others (13, 14 and 15).

There is no significant difference between both groups regarding the need for other uterotonics drugs (13.3\% versus $16.7 \%)$. These results agree with what was published before (13), but do not agree with other previous studies $(12,14,15,16 \& 17)$.

In 1999, a study performed (12) RCT on 694 patients comparing the incidence of PPH in women undergoing elective Caesarean section who received either carbetocin as a $100 \mu \mathrm{g}$ IV bolus or oxytocin as a continuous infusion for 8 hours (25 IU of oxytocin in $1000 \mathrm{~mL}$ of Ringer's lactate, $125 \mathrm{~mL}$ per hour).. The carbetocin group had decreased need for therapeutic oxytocics $(4.7 \%$ vs. $10.1 \% ; \mathrm{P}<0.05)$ [12]. The difference between these results and our scan can be explained by the difference in the studied populations.

A group of researchers did a randomized study on 160 women undergoing vaginal delivery with at least one risk factor for PPH to receive either carbetocin $100 \mathrm{mg}$ IM or oxytocin 10 IU IV oxytocin infusion over 2 h. The need for uterine massage and other uterotonics were significantly lower in the carbetocin group [13]. These results are in agreement with ours. However, they found no significant difference in the amount of bleeding or the hemoglobin difference before and after delivery between the groups. The difference between these results and ours can be explained by the difference in the route and dose of oxytocin used in our study and theirs.

In a double-blind randomized study on 377 women undergoing cesarean sections receiving either carbetocin $100 \mathrm{mg}$ or oxytocin 5 IU intravenously after the delivery of the baby. The carbetocin group needed significantly less uterotonic results (33.5\% versus $45.5 \%$, Relative risk 0.74, 95\% CI 0.57-0.95). On the other hand, they found no significant difference in the blood loss or difference in hemoglobin before and after the operation between the two groups [14].

A study was performed to compare the hemodynamic effects of oxytocin and carbetocin and to assess the efficacy of these two drugs in terms of blood loss and the 
additional uterotonic needed in caesarean section at high risk of primary postpartum hemorrhage. One hundred and two women undergoing cesarean sections receive either $20 \mathrm{IU}$ of oxytocin in $1000 \mathrm{ml}$ of $0.9 \% \mathrm{NaCl}$ solution IV or carbetocin $100 \mathrm{mcg}$ IV bolus. More women needed additional uterotonic agents in the oxytocin group (23.5\% vs. $0 \%$, $\mathrm{p}<0.01$ ), though there was no significant difference in estimated blood loss and in the dropped hemoglobin level. There was a significant difference in the diuresis, higher in carbetocin group [15].

A double-blinded randomized study was conducted on 200 pregnant women with at least two risk factors for developing atonic PPH, randomized into two groups: Group 1 (100 women) received single $100 \mathrm{mg}$ IM dose of carbetocin and Group 2 received of 5 IU oxytocin IM. Both groups received their drug after fetal and before placental delivery. There was a statistically significant difference between the two study groups regarding amount of bleeding (337.73 \pm 118.77 versus $378 \pm 143.2$ ), occurrence of PPH (4\% versus 16\%), need for other uterotonics (23\% versus $37 \%)$ and hemoglobin difference between before and after delivery $(0.55 \pm 0.35$ versus $0.96 \pm$ 0.62) (all being lower in carbetocin group) and measured hemoglobin $24 \mathrm{~h}$ after delivery (being higher in carbetocin group). On the other hand, there was no significant difference between the two groups regarding occurrence of major $\mathrm{PPH}$ and the need for blood transfusion. Regarding drugs side effects, there was no significant difference between the two groups regarding occurrence of nausea, vomiting, flushing, dizziness, headache, shivering, metallic taste, dyspnea, and palpitations and itching. The incidence of tachycardia was significantly higher in the carbetocin group [16].

In another randomized controlled trial which included 350 singleton pregnant women who delivered were 20 years or older, had a gestational age of at least 34 weeks, had a vaginal delivery, and had at least one risk factor for atonic PPH. 176 women received $100 \mathrm{mcg}$ carbetocin IV immediately after placental delivery, while 174 women received $5 \mathrm{U}$ oxytocin IV. Postpartum blood loss was measured objectively in $\mathrm{mL}$ using a postpartum drape with a calibrated bag. The carbetocin group had less postpartum blood loss $(146.7 \pm 90.4$ vs. $195.1 \pm 146.2 \mathrm{~mL}$; $\mathrm{p}<$ 0.01 ), a lower incidence of atonic PPH (0 vs. $6.3 \% ; \mathrm{p}<0.01)$, less usage of additional uterotonic drugs (9.1 vs. $27.6 \%$; p $<0.01)$, and a lower incidence of postpartum anemia $(\mathrm{Hb} \leq 10 \mathrm{~g} / \mathrm{dL})(9.1$ vs. $18.4 \% ; \mathrm{p}<0.05)$ 
than the oxytocin group. No significant differences regarding side effects were evident between the groups [17].

The adverse effect profiles appear reassuringly similar between the two medications, the risk of experiencing nausea, vomiting, abdominal pain, flushing, tachycardia, hypotension, headache, itching, metallic taste were similar in women given oxytocin and carbetocin.

There have also been randomized studies of carbetocin versus syntometrine following vaginal birth (18, 19 and 20). All those studies excluded women with significant risk factors for $\mathrm{PPH}$. The syntometrine dose was the approved dose (a mixture of $5 \mathrm{IU}$ oxytocin and $0.5 \mathrm{mg}$ ergometrine) in some studies (18 \& 19), and lower than the approved dose in 1 study (that is, ergometrine component $0.2 \mathrm{mg}$ rather than $0.5 \mathrm{mg}(20)$

However, all studies showed that carbetocin was associated with a significantly lower incidence of adverse effects. One of those studies showed that carbetocin was associated with a lower incidence of hypertension at 30 and 60 minutes but a higher incidence of maternal tachycardia. (18).

A study compared the efficacy and safety of intramuscular (IM) carbetocin with IM syntometrine in preventing primary $\mathrm{PPH}$ in a prospective, double-blinded, randomized controlled trial. They found that IM carbetocin was as effective as IM syntometrine in preventing primary $\mathrm{PPH}$ after vaginal delivery. It was less likely to induce hypertension and had a low incidence of adverse effect. So, it should be considered as a good alternative to conventional uterotonic agents used in managing the third stage of labor [18].

In a double-blind randomized study was carried out on 370 women with singleton pregnancy achieving vaginal deliveries at or beyond 34 weeks. Women with risk factors for postpartum haemorrhage excluded from the study. Women were randomized to receive either intramuscular syntometrine or intramuscular carbetocin. No significant difference in PPH and addition uterotonics (carbetocin $13.5 \%$ vs Syntometrine 16.8\%; $\mathrm{P}=0.38$ ). Carbetocin associated with less adverse effects [19].

In another double blind randomized clinical trial was carried out on 200 pregnant women with a singleton pregnancy. The first group received intramuscular syntometrine (containing 5 units of oxytocin and $0.2 \mathrm{mg}$ ergometrine) and the second group received intramuscular carbetocin after placental delivery. The mean fall in hemoglobin level 
in the carbetocin group was significantly lower than the syntometrine group $(\mathrm{P}<$ 0.001). Also there were significant differences between the two groups, regarding additional uterotonic drug requirements $(\mathrm{P}=0.002)$. Moreover systolic blood pressure and uterine tone immediately and 30 minutes after drug administration were significantly different $(\mathrm{P}<0.001)$. Incidence rate of tachycardia in the carbetocin group was $13 \%$, in contrast to $5 \%$ in the syntometrine group $(\mathrm{P}=0.04)$ [20].

\section{Conclusion:}

We concluded that carbetocin is a better alternative to traditional oxytocin in prevention of PPH after vaginal delivery in women with risk factors for atonic PPH with similar side effects and could be routinely used to prevent $\mathrm{PPH}$, which represents the main deaths among parturient women. More trials in low-risk women who undergo vaginal delivery are needed to assess whether carbetocin is superior to conventional uterotonic drugs for the majority of pregnant women.

\section{References}

1- Shakur H, Elbourne D, Gülmezoglu M, Alfirevic Z, Ronsmans C, Allen E, Roberts I. The WOMAN Trial (World Maternal Antifibrinolytic Trial): tranexamic acid for the treatment of postpartum haemorrhage: an international randomised, double blind placebo controlled trial. Trials. 2010 Dec;11(1):40.

2- Mousa HA, Blum J, El Senoun GA, Shakur H, Alfirevic Z. Treatment for primary postpartum haemorrhage. Cochrane database of systematic reviews. 2014(2).

3- Abdul-Kadir R, McLintock C, Ducloy AS, ElRefaey H, England A, Federici AB, Grotegut CA, Halimeh S, Herman JH, Hofer S, James AH. Evaluation and management of postpartum hemorrhage: consensus from an international expert panel. Transfusion. 2014 Jul;54(7):175668.

4- Buzaglo N, Harlev A, Sergienko R, Sheiner E. Risk factors for early postpartum hemorrhage $(\mathrm{PPH})$ in the first vaginal delivery, and obstetrical outcomes in subsequent pregnancy. The Journal of Maternal-Fetal \& Neonatal Medicine. 2015 May 24;28(8):932.

5- Leduc D, Senikas V, Lalonde AB, Ballerman C, Biringer A, Delaney M, Duperron L, Girard I, Jones D, Lee LS, Shepherd D. Active management of the third stage of labour: prevention and treatment of postpartum hemorrhage. Journal of obstetrics and gynaecology Canada. 2009 Oct 1;31(10):980-93.

6- Rath W. Prevention of postpartum haemorrhage with the oxytocin analogue carbetocin. European Journal of Obstetrics \& Gynecology and Reproductive Biology. 2009 Nov 1;147(1):1520.

7- Sheldon WR, Durocher J, Winikoff B, Blum J, Trussell J. How effective are the components of active management of the third stage of labor?. BMC pregnancy and childbirth. 2013 Dec;13(1):46.

8- Moertl MG, Friedrich S, Kraschl J, Wadsack C, Lang U, Schlembach D. Haemodynamic effects of carbetocin and oxytocin given as intravenous bolus on women undergoing caesarean delivery: a randomised trial. BJOG: An International Journal of Obstetrics \& Gynaecology. 2011 Oct;118(11):1349-56.

9- Cordovani D, Carvalho JC, Boucher M, Farine D. Carbetocin for the prevention of postpartum hemorrhage. A Comprehensive textbook of postpartum hemorrhage: an essential clinical reference for effective management, 2nd edn. Sapiens Publishing, London. 2012:361-8. 
10-Meshykhi LS, Nel MR, Lucas DN. The role of carbetocin in the prevention and management of postpartum haemorrhage. International journal of obstetric anesthesia. 2016 Dec 1;28:61-9.

Therapeutics. 1992 Jul;52(1):60-7.

12-Dansereau J, Joshi AK, Helewa ME, Doran TA, Lange IR, Luther ER, Farine D, Schulz ML, Horbay GL, Griffin P, Wassenaar W. Doubleblind comparison of carbetocin versus oxytocin in prevention of uterine atony after cesarean section. American journal of obstetrics and gynecology. 1999 Mar 1;180(3):670-6.

13-Boucher M, Nimrod CA, Tawagi GF, Meeker TA, White RE, Varin J. Comparison of carbetocin and oxytocin for the prevention of postpartum hemorrhage following vaginal delivery: a double-blind randomized trial. Journal of Obstetrics and Gynaecology Canada. 2004 May 1;26(5):481-8.

14-Attilakos G, Psaroudakis D, Ash J, Buchanan R, Winter C, Donald F, Hunt LP, Draycott T. Carbetocin versus oxytocin for the prevention of postpartum haemorrhage following caesarean section: the results of a double-blind randomised trial. BJOG: An International Journal of Obstetrics \& Gynaecology. 2010 Jul;117(8):92936.

15-Larciprete G, Montagnoli C, Frigo M, Panetta V, Todde C, Zuppani B, Centonze C, Bompiani A, Malandrenis I, Cirese A, Valensise $\mathrm{H}$. Carbetocin versus oxytocin in caesarean section with high risk of post-partum haemorrhage. Journal of prenatal medicine. 2013 Jan;7(1):12.

16-Maged AM, Hassan AM, Shehata NA. Carbetocin versus oxytocin for prevention of
11-Hunter DJ, Schulz P, Wassenaar W. Effect of carbetocin, a long-acting oxytocin analog on the postpartum uterus. Clinical Pharmacology \&

postpartum hemorrhage after vaginal delivery in high risk women. The Journal of Maternal-Fetal \& Neonatal Medicine. 2016 Feb 16;29(4):532-6.

17-Amornpetchakul P, Lertbunnaphong $\mathrm{T}$, Boriboonhiransarn D, Leetheeragul J, Sirisomboon R, Jiraprasertwong R. Intravenous carbetocin versus intravenous oxytocin for preventing atonic postpartum hemorrhage after normal vaginal delivery in high-risk singleton pregnancies: a triple-blind randomized controlled trial. Archives of gynecology and obstetrics. 2018 Aug 1;298(2):319-27.

18-Leung SW, Ng PS, Wong WY, Cheung TH. A randomised trial of carbetocin versus syntometrine in the management of the third stage of labour. BJOG: An International Journal of Obstetrics \& Gynaecology. 2006 Dec;113(12):1459-64.

19-Su LL, Rauff M, Chan YH, Mohamad Suphan N, Lau TP, Biswas A, Chong YS. Carbetocin versus syntometrine for the third stage of labour following vaginal delivery - a double-blind randomised controlled trial. BJOG: An International Journal of Obstetrics \& Gynaecology. 2009 Oct;116(11):1461-6.

20-Samimi M, Imani-Harsini A, AbedzadehKalahroudi M. Carbetocin vs. syntometrine in prevention of postpartum hemorrhage: a double blind randomized control trial. Iranian Red Crescent Medical Journal. 2013 Sep;15(9):817.

To cite this article: Mahmoud A. Abdelfath, Khaled M. Salama, Yehia M. Samir Edris, Amany M. Metwally. Carbetocin versus Oxytocin in the Prevention of Postpartum Hemorrhage Following Vaginal Delivery in High Risk Patients. BMFJ 2022;39(1):112-122. DOI: 10.21608/bmfj.2022.17612.1083 